\title{
Correction to: Finite element error estimates in non-energy norms for the two-dimensional scalar Signorini problem
}

\author{
Constantin Christof ${ }^{1} \cdot$ Christof Haubner $^{2}$
}

Published online: 21 June 2021

(c) The Author(s) 2021

\section{Correction to: Numerische Mathematik (2020) 145:513-551 https://doi.org/10.1007/s00211-020-01117-z}

The article "Finite element error estimates in non-energy norms for the two-dimensional scalar Signorini problem", written by Constantin Christof and Christof Haubner, was originally published Online First without Open Access. After publication in volume 145, issue 3, page 513-551 the author decided to opt for Open Choice and to make the article an Open Access publication. Therefore, the copyright of the article has been changed to (C) The Author(s) 2020 and the article is forthwith distributed under the terms of the Creative Commons Attribution 4.0 International License, which permits use, sharing, adaptation, distribution and reproduction in any medium or format, as long as you give appropriate credit to the original author(s) and the source, provide a link to the Creative Commons licence, and indicate if changes were made. The images or other third party material in this article are included in the article's Creative Commons licence, unless indicated otherwise in a credit line to the material. If material is not included in the article's Creative Commons licence and your intended use is not permitted by statutory regulation or exceeds the permitted use, you will need to obtain permission directly from the copyright holder. To view a copy of this licence, visit http://creativecommons.org/licenses/by/4.0.

Open access funding enabled and organized by Projekt DEAL.

Original article has been corrected.

Publisher's Note Springer Nature remains neutral with regard to jurisdictional claims in published maps and institutional affiliations.

The original article can be found online at https://doi.org/10.1007/s00211-020-01117-z.

Constantin Christof

christof@ma.tum.de

1 Chair of Optimal Control, Center for Mathematical Sciences, Technische Universität München, Boltzmannstraße 3, 85748 Garching, Germany

2 Institut für Mathematik und Computergestützte Simulation, Universität der Bundeswehr München, Werner-Heisenberg-Weg 39, 85577 Neubiberg, Germany 